Organising Regionally for Natural Resource Management in Australia: Reflections on Agency and Government

SUSAN A. MOORE* \& SUSAN F. ROCKLOFF**

* Murdoch University, Perth, Australia

** Central Queensland University, Rockhampton, Australia [Corresponding author: Centre for Social Science Research, Central Queensland University, Rockhampton, Queensland 4702 AUSTRALIA. Ph: +61 74930 9239. Fax: +61 74930 6402. Email: s.rockloff@cqu.edu.au. 


\section{Organising Regionally for Natural Resource Management in Australia: Reflections on Agency and Government}

ABSTRACT The Australian Government is leading efforts to affect nationwide changes in how natural resources are managed, specifically the country's agricultural areas and rangelands. The focus is organising regionally, with community-based groups planning for and managing the delivery of millions of dollars of resource management works. This paper analyses these arrangements from the ideal of democratic decentralisation, drawing on interviews with key informants in two Australian states (Victoria and Western Australia) and participant observation. Centring the analysis on representation, accountability, fairness and the secure transfer of power indicates that this ideal is far from being achieved. Although unachieved, opportunities for agency by local people exist and continue to develop. Given the strong directing roles of the Australian Government in these regionalising efforts, the paper concludes with comments about their potentially important role in progressing democratic decentralisation.

\section{Introduction}

Australia is currently involved in a flurry of natural resource management activities, in response to a number of reports identifying high levels of degradation of the country's lands, soils, wildlife, and inland and coastal waters (e.g. Wentworth Group, 2002). These problems are affecting agricultural productivity as well as biodiversity, public infrastructure and health, and Australian living standards (Curtis \& Lockwood, 2000). Agricultural production is an important contributor to Australia's economy, providing $22 \%$ of the total value of Australia's exports of goods and services in 1996 (Bellamy \& Johnson, 2000). Much of this natural resource management (NRM) activity is currently 
focused on regions, and the agricultural lands within them, where these regions are an administrative entity below the national and state (provincial) scales.

A total of $60 \%$ of the Australian continent is occupied by agricultural and pastoral activities (Bates, 2003), most on privately owned lands or areas with long-term leases and lessees who express strong 'traditional' property rights. Thus, although governments might chose to regulate private landholders to affect land use change, such an approach is unlikely to be politically palatable. Rather, Australian governments have used voluntary approaches over the last two decades, based on education and grants schemes, to stimulate and support the adoption of more sustainable land use practices.

In parallel to these efforts to affect land use changes, a diversity of approaches to regional governance has blossomed nationally and internationally (Dale \& Bellamy, 1998; Dore et al., 2003; Jennings \& Moore, 2000; McGinnis et al., 1999). The reasons for moving towards regional delivery are numerous, but most rationales include a strong undercurrent, if not explicit goals, of improved participation and engagement by local people. Community-based natural resource management (CBNRM), often achieved through organising regionally, has been widely advocated as both a way of more efficiently managing the environment and its resources while at the same time improving equity and justice for local people (Kellert et al., 2000; Lane et al., 2004; Ribot, 2002).

Democratic decentralisation has been identified as pivotal to making CBNRM effective (Ribot, 2002; Virtanen, 2003). It occurs when 'powers and resources are transferred to authorities representative of and downwardly accountable to local populations' (Ribot, 2002, 4). Transfer is usually of State assets or powers to local or regional, and often non-government, decision-making bodies (Lane et al., 2004). Both 
power transfers and accountable representation are needed for democratic decentralisation to work (Ribot, 2002). In NRM, decentralisation through regional delivery has become an important part of the environmental policy landscape (Lane et al., 2004).

This paper analyses the extent to which the current regional delivery of NRM in Australia matches the ideal of democratic decentralisation. The analysis begins with a brief overview of the pivotal government programs. The distance between reality and the ideal is then explored using key attributes of democratic decentralisation representation, accountability, fairness and the secure transfer of power (Agrawal, 2000; Lane et al., 2004; Ribot, 2002). The last part of the paper comments on the opportunities for agency (i.e. the ability to act freely and guide decision-making) by people in the regions in the face of limited democratic decentralisation and the important but complex role for the Australian Government in progressing achievement of this ideal.

\section{Regional Delivery of Natural Resource Management in Australia}

Australia has three tiers of government - Commonwealth (national), state and territorial (6 and 2 respectively), and local (shire/county) - collectively referred to as the Australian Government. Responsibility for land use decision-making and therefore environmental protection has historically rested with the States, although Commonwealth powers, embedded in the country's constitution, can be used to override the States (Bates, 2003). Today, cooperative federalism characterises many of the arrangements between the three tiers, with the Commonwealth taking an initiating and coordinating role in developing national policies and then the states and local government assisting in their implementation. Today's regional delivery arrangements 
for NRM, for example, are based on bilateral agreements and associated funding arrangements, initiated and directed by the Commonwealth Government, and between this tier of government and each State and Territory.

Strong Commonwealth direction of NRM, and specifically for improvements in the management of agricultural lands and the rangelands, began in 1988 with the commitment of AUD\$360 million to the Decade of Landcare (Curtis et al., 2002). Funding was predominantly for education and demonstration activities. Landcare has been acknowledged nationally and internationally as a success because of the activation and activities of voluntary, community groups. There are now over 4,000 Landcare-type groups in Australia with around 120,000 members, involving about $30 \%$ of the farming community (Curtis \& Lockwood, 2000). In 1997, the Commonwealth Government's Natural Heritage Trust Program (NHT) and the NHT Extension (in 2001) modified the Landcare approach and placed more emphasis on funding on-ground works on private lands.

The major change and shift to regional delivery occurred in 2000 when the Commonwealth Government announced the regionally-based National Action Plan for Salinity and Water Quality Program (NAP) to be implemented via 21 priority catchments across Australia (Commonwealth of Australia 2004). This shift was a response to concerns with the efficiencies and effectiveness of the Landcare and NHT approaches (CIE \& CSIRO, 1999; Curtis, 2003; Working with People, 2004). The NHT Extension similarly takes a regional approach, based on 56 regions. Regional plans and accompanying investment strategies have been completed by most regions and once 'accredited' by the Commonwealth and relevant state or territory government, 
investment monies flow to the region (Commonwealth of Australia, 2005), predominantly from the Commonwealth and relevant State Government.

There are significant differences between the Landcare 'paradigm' and the emerging regional approach on almost every front (Table 1). Regional groups are expected to have a much more strategic, corporate role, to be able to plan and make decisions across their region, and have sound business arrangements for reporting and financial management. To investigate this emerging regional approach, key informants from two regional NRM groups in Western Australia and two in Victoria (Table 2) were interviewed to investigate governance arrangements and aspirations. The Victorian groups have a statutory basis under the Victorian Catchment and Land Protection Act 1994, while the Western Australian groups are non-statutory. All four groups have been operational for 10 or more years and all identified their role as developing and implementing a regional strategy.

\section{INSERT TABLES $1 \& 2$ NEAR HERE}

The population of the four regions ranges from 42,000 (a sparsely populated region with many small towns with declining populations) to 1.4 million (includes the capital city Perth, plus a number of large and small towns). Together, the regions encompass a diversity of land uses - from the Avon Catchment dominated by broad acre farming, with an increasing number of lifestyle smallholdings, to the Swan Catchment with horticulture, viticulture and manufacturing and the urban areas of Perth. The two Victorian regions include dryland farming, cropping, dairying, blue gums (Glenelg Hopkins Catchment) and mixed farming with increasing lifestyle farming on smallholdings (North East Catchment). 


\section{Regional Delivery as Democratic Decentralisation - An Analysis}

\section{Representation}

The key informants together described a wide range of approaches to how representatives are selected and appointed. In Victoria, members are appointed by the Minister for Environment and Conservation according to the Catchment and Land Protection Act 1994 (Victoria). Potential members identify themselves through an expression of interest where they address required skills (Table 2). The Minister takes these skills into account, plus advice from senior government advisors and the Victorian Catchment Management Council. High numbers of people nominate - most recently 100 for the 13 community positions on NECMA and 87 for the 13 positions on the GHCMA. The Victorian groups are required by their Act to include a representative of the Department of Sustainability and Environment; and at least half of the members must have primary production as their principal occupation.

In Western Australia, there is no Ministerial appointment. The Avon Catchment Council is the closest to elected representation, where the three sub-regions comprising the Avon Catchment nominate potential members. Nominations are then entered on a ballot paper and sent for election to Land Conservation District Committees (local government level land management committees, with Ministerially appointed members) and local government authorities within each of the sub-regions. Although seemingly democratic, this process is not fully democratic as some areas do not have a Land Conservation District Committee, other have defunct ones and very few non-farming people feel able or are encouraged to be involved. The Swan Catchment Council has a less democratic process than the Avon where, although community members are nominated by the six sub-regions, they are then selected by the Council rather than a list 
of names being returned to the sub-regions for voting. To-date it has been unusual to receive more than one nomination from each sub-region, pre-empting the need for elections.

Having explored how representation is achieved, it is also critical to identify those parts of society represented on and missing from these NRM groups. If democratic approaches are desired, then those making the decisions (i.e. the members of the NRM groups) must represent the demos (Moore, forthcoming), where 'the demos should include all adults subject to the binding collective decisions of the association' (Dahl 1989: 120). For regional Australia, the demos can be divided, for the sake of this analysis, into those geographically located within a region and those outside.

Within a region, the demos is likely to be highly diverse, including landholders with large through to small agricultural holdings, residents of rural towns and cities of all sizes, indigenous interests, environmental groups, recreation and tourism interests, and ethnic groups. The notion that there is a homogeneous regional community of locale has been de-bunked by academics and practitioners alike (Lane et al., 2004). Of all these interests, agriculture is the one predominantly, currently represented on regional NRM groups.

One of the Victorian groups was concerned that representation based on 'one person, one vote' could lead to regional groups being dominated by interests from rural towns, given that the regional, urban population in parts of Victoria is much larger than the regional, farm-based population. Such domination was noted as problematic because the responsibility for action was perceived as resting with rural landholders.

Interests currently outside the region, but still potentially influenced by regional decisions, includes the broader public interested in the expenditure of public funds, 
environmentalists, and future generations. Government representatives on the regional groups have an important role in representing the broader public, as well as mediating against the 'privatising' of environmental governance (Lane, 2003a), where public resources and arguably public goods, such as biodiversity and water quality, are managed by regional groups dominated by private interests. Environmental groups have been promoted as representatives of unborn generations and non-human objects (Dobson, 1996). All groups reviewed had some level of government representation, especially the WA groups where one quarter to a third of members were from the State Government (Table 2). The Swan Catchment Council was the only one of the four to explicitly include representatives of indigenous interests and biodiversity. Indigenous interests have been long marginalised from NRM in Australia (Lane, 2003b).

\section{Accountability}

Representation and the requirement for accountability go hand in hand. Not only should local institutions be representative, they must be accountable, if democratic decentralisation is to become a reality (Ribot, 2002). Clear sources of authority and accountability to those represented are essential for deliberative democracy (O’Neill, 2001). Of particular interest is 'downward accountability' to local people where these people chose their own representatives who deliberate and decide on their behalf (Ribot, 2002).

Three accountability directions were evident from the regional groups reviewed upward, downward and sideways. In terms of upward accountability, all groups identified themselves as accountable to the Commonwealth Government, as a fundor and driver of their regional activities. The Victorian groups also saw themselves as upwardly accountable to their State Government because they have responsibility and 
funding for managing waterways, on the Government's behalf. In Western Australia, where no such requirements rest with the regional bodies, the accountability relationship with the State Government was expressed very differently, as a partnership or sideways accountability rather than an upward accountability (Table 3).

\section{INSERT TABLE 3 NEAR HERE}

This sideway accountability brings into clear relief the struggles for agency that can accompany efforts to decentralise NRM. In Western Australia, the groups reviewed were finding it difficult to get information from the State Government agencies on how they were spending their funds within the partnership arrangements. As one informant noted:

The partnership arrangements with State Government are not well suited to open accountability. The regional group needs the skills and ability to negotiate with agencies to ensure accountability...At present, agencies can 'over-ride' the regional NRM groups as they assume that they hold the administrative expertise...Some agencies provide good information, other are less open and accountable.

Downward accountability also brought different responses from the groups. The Victorian groups did not regard themselves as accountable to their regional communities (Table 3). The Western Australians talked about accountability to regional communities, but only through the provision of information and open meetings. They did not explicitly engage with how they might formalise accountability arrangements with their regional constituents.

Electing representatives is one such way of formalising downward accountability arrangements (Ribot, 2002). Through elections, voters usually have a choice between candidates and can use the election process to displace perceived poor performers. 
There are also great incentives for elected members to listen to their constituents so they will receive their vote next time. Such processes also keep open two-way communication as well as creating formal accountability arrangements between the represented and their representative. Only the WA groups have elected representatives, however, they are elected from a limited part of the demos - rural landholders with an existing interest in NRM.

Ribot (2002) advocates building on existing local representative, accountable institutions. In Australia, this suggests working closely with local government. In the interviews, concern was expressed that using elected representatives from local government processes would risk introducing the parochial attitudes regarded as characterising much of local government in Australia. Respondents were very clear that effective NRM depended on group members who had a regional rather than parochial (local) mind-set. Respondents were also concerned that having elected rather than nominated members could result in much-needed skills being lost from the groups. At the moment, membership of groups, especially the Victorian ones, relies on skills-based nomination.

All four groups identified good corporate governance as an essential element of accountability, although the West Australians spent more time talking about it. Several reasons account for this greater attention to governance in Western Australia. In Victoria, the catchment management authorities have been in place, and have had responsibilities for managing budgets and staff, for a number of years (Ewing, 2003). In contrast, the WA regional groups reviewed formed only a decade ago and have had predominantly non-statutory planning and public consultation roles, rather than any managerial or administrative functions. It is only recently with the advent of NAP and 
the NHT Extension that they have needed to manage large project-directed budgets and develop corporate governance skills.

\section{Fairness}

An important element of NRM is judgments about fairness (Smith \& McDonough, 2001). The acceptability or otherwise of management decisions may hinge on whether the associated decision making processes were perceived as fair (Webler et al., 2001). As such, the analysis of democratic decentralisation in this paper has been expanded beyond considering representation, accountability and power transfers (Ribot, 2002) to include fairness. Analysing fairness provides insights to equity, itself a central concern of democratic decentralisation (Ribot, 2002), as well as offering comment on the acceptability of decision-making.

Several normative statements regarding fairness and decision-making relevant to NRM are worth making:

(1) In democratic societies, those likely to be affected by a decision should be involved (or at least represented) in decision-making;

(2) Management of public resources should be based on equitable, democratic deliberation (Lane, 2003a); and

(3) A significant proportion of the population will accept a difficult decision if they believe the decision-making process was fair, irrespective of the outcome (Douglas \& Wildavsky, 1982).

Regional delivery of natural resources management, via an accredited regional plan and investment strategy, will result in winners and losers. As part of this regional planning, each group has established investment priorities. For three of the four groups, 
these priorities were strongly influenced by the Commonwealth and State Governments. These Governments either set the priorities, as was the case for the Victorian groups, or used their technical expertise to identify assets and hence priorities, as was the case with the Avon Catchment Council. In Victoria this level of government direction is accepted. The Avon Catchment Council in Western Australia, while accepting that such direction was currently needed because of the limited skills available in the broader community, aspire to greater independence in the future. The Swan Catchment Council was the only group where its own deliberations took centre stage.

All of the groups talked about their priority-setting process as being fair within their regional group but that from outside the process may not be perceived as fair at all (Table 4). Reasons for perceptions of fairness within the group included representing all interests, decisions having a technical basis, and meeting the requirements of the Commonwealth (e.g., focusing on priority targets as required by the Commonwealth). The link with representation emphasises its contribution to perceptions of fairness. The make up of councils and similar bodies involved in NRM has previously been identified as important to fairness (Webler et al., 2001). Using the right information, here information with technical merit, was also identified by these authors as essential for good public participation processes.

\section{INSERT TABLE 4 NEAR HERE}

Concerns about fairness, the predicted judgement from the outside (Table 4, column 3), were linked to outcomes - the regional strategies with their targeted investments will result in winners and losers and hence will be socially inequitable. A significant part of this concern with equity stems from previous funding arrangements where landholders in rural areas, usually as part of a small collective, applied for funds 
from the Commonwealth and State Governments to undertake on-farm works such as tree planting and fencing. These applications were usually successful and many Landcare groups became proficient at writing grants and administering small projects.

Regional delivery through an accredited plan and investment strategy means funding of large-scale, priority projects where there are high value assets or threats. Landholders who do not have high priority assets or threats are unlikely to receive money through these regional strategies. The Victorian groups were concerned about the equity implications, with landholders questioning the fairness of the process once they realised they would not get the outcomes (i.e. access to funding) they expected. Many landholders are not yet aware of this significant change in funding arrangements (Working with People 2004).

\section{Secure Transfer of Power to Local People}

For sustainable decentralisation to be achieved, and governance to be democratic, some secure form of power transfer from central governments to local bodies must be achieved. Security is best achieved through constitutional, legislative or administrative means (Ribot, 2002). Statutory regional bodies are an example of regionalisation based on legislation. Both the statutory and non-statutory groups saw benefits from being statutory. The statutory basis for the Victorian groups means that they are corporate bodies, with a specified membership and means of appointment. They noted that being statutory gave them credibility with the community, as they are able to carry out their responsibilities - for example, undertake and/or fund waterways and floodplain management. They also have more security than the non-statutory WA groups.

The Western Australian groups saw being statutory as giving them credibility with the State Government. Such credibility would enable them to be equal partners in 
setting priorities and accessing information. Confusion currently exists around being 'statutory', with many of those involved in regional matters equating being statutory with having Ministerially-appointed members. In reality, statutory means establishing the groups under law (e.g. having legislation that establishes and recognises such groups) (Bates, 2003). The choice can then be made independently as to how members might be identified and selected. The mechanism for selection may or may not be part of the statute. Several of the WA informants expressed an interest in becoming statutory but were concerned they would lose the benefits of elected/community-nominated members. This concern is, in a large part, a product of this confusion.

The transfer of power is the other part of the equation. For regional groups, this power has at leat two potential sources - power devolved downwards from the Australian Government and power afforded the group through representing regional people. Certainly efforts are being made to devolve power to regional groups through support for regional planning and associated investment. And, being statutory provides a basis for permanency and long-term stability. Without such longer-term security, real transfer of power from the Commonwealth and State Governments is unlikely (Ribot, 2002). Rather than decentralisation, it is more likely that the process underway is one of deconcentration where, although power is transferred to lower level actors, they remain accountable to their superiors. With decentralisation, power is similarly transferred, but the lower level actors are accountable downwards to their constituencies (Virtanen, 2003).

Several of the key respondents saw value in ignoring democracy in the pursuit of natural resource outcomes. They defined successful regional delivery as prioritising and efficiently implementing actions to achieve targets for improved resource condition. 
Whether these targets are best for regional people was not considered. Several illustrative quotes follow:

Prioritisation of targets and actions according to the strategy will ensure that investment is made where it is required rather than where most people want it to be.

A few in the community considered that the Board should be democratically elected, however, as a skills-based Board it is more efficient in the regional delivery of NRM.

Several arguments were also put as to why regional groups should not be democratic, the rationale being that the groups are there to make decisions for which they are (financially) accountable and as such democratic principles are unimportant. This view probably reflects the outcome-based focus and 'changes on-the-ground mantra' of the Natural Heritage Trust (Commonwealth of Australia, 2005) as well as landholders' interests in getting on with the job rather than talking about it (Byron, 2004). In Victoria the lack of clear, formal links for decision making, between regional communities and the regional groups, was noted as precluding democratic processes.

\section{Democratic Decentralisation, Agency and Government}

Democratic decentralisation relies on people being able to act and apply themselves to decision making, and in the context of this paper, to the decisions and actions associated with NRM. What are the opportunities for regional people to have agency (i.e. the ability to act) in these processes, while recognising the strong directing roles of the Commonwealth and State Governments? And what is the role of the Australian Government in progressing democratic regional delivery?

The opportunities available for local agency through the existing selection processes for members differ between the states. For the Victorians, the 'expression of 
interest' process means that only those who know that calls for expressions are out or who are personally invited to nominate will be included. Only those with the power and/or knowledge to apply will do so (Ewing, 2003). The opportunities for agency appear limited for those without knowledge, connections and/or influence. The Western Australian situation offers more opportunities, particularly with the Avon Catchment Council where two-thirds of members are elected by local government instrumentalities.

Counter-intuitively, relying on nominated representatives offers opportunities for agency in the broadest sense of picking up representatives of societal sectors potentially under-represented, such as indigenous interests and biodiversity. The Swan Catchment Council, for example, includes 'elected' representatives, plus several others selected specifically for their skills (e.g., biodiversity, indigenous interests). Thus, requiring representation of certain interests, a highly prescriptive approach, may paradoxically result in greater collective agency for diverse regional communities.

Agency for most local people, all those who are not members of regional bodies, is restricted by the lack of downward accountability by regional bodies. For local people there are few means available for influencing the choice or actions of members of regional groups or for recourse if their actions are unacceptable. This lack of downward accountability is exacerbated by representation based on appointment rather than election. Because of these issues with accountability and the importance of elected representation a more prominent place for elected local authorities (in Australia, local government) in NRM is being increasingly advocated (Dovers, 2003; Ribot, 2002).

The agency of the regional groups themselves is also constrained, specifically by the bilateral agreements between the Commonwealth and State Governments and the 
criteria for accreditation. These criteria limit what can be addressed, funded and implemented, with improvements in resource condition being the current, desired, broad outcome. However, even within this restrictive context, the chairs of the Western Australian regional groups have formed a State-level group to develop and co-sign a memorandum of understanding with the State Government to clarify their relative roles and responsibilities. The target-based approach set by the Commonwealth (Commonwealth of Australia, 2005) and the short timeframes for preparing the regional strategies does not easily accommodate democratic processes. The regional groups have been expected to rapidly set targets for resource conditions, consult with local communities (over a short period of weeks rather than months) and then oversee implementation of the regional plans.

Although the transfer of power to local authorities is regarded as pivotal to democratic decentralisation (Ribot, 2002), good reasons exist to carefully consider and temper this transfer. If the local group is not representative, decision-making will not comprehensively reflect the views of local people. Even more vexing, the group may be representative, but of narrow local interests (Lane et al., 2004). If this is the case, wider societal concerns will be neglected. Thoughts of transfer must also be tempered by recognising that public as well as private goods are involved so means must be retained for accounting for the public interest. The public interest, with regard to broadscale issues such as trans-state water management and biome-based nature conservation, may be better pursued and accounted for by State Government agencies who are in turn accountable to elected representatives in State parliaments.

The Commonwealth and State Governments have strong roles in guiding the groups and as members. The relationship between community members and the State 
Government appears more contested and at the same time more amenable to local agency than does the community-Commonwealth relationship. For the Victorians, the regional members acknowledge their role in implementing state requirements but there is some optimism that the new process will allow them to pursue greater flexibility in their NRM activities. The Western Australian situation is even more interesting, with the arrangement with the State Government described as a partnership. Here, there are pressures on the state from community members to be more accountable, accompanied by efforts to enhance the skills of community members so the co-production of knowledge with the state (Lane, 2003a) is possible. Opportunities for local agency clearly exist in these state-community relationships in Western Australia.

Although the power relations between governments and community members in these regional groups are asymmetric in the government's favour (Agrawal, 2000), there are essential reasons for governmental involvement. Government representatives can reflect and account for the broader public interest and potentially mediate between conflicting community interests (Lane et al., 2004). There are also reasons for retaining this asymmetry. As Ribot $(2002,16)$ describes:

Many powers belong with central government, such as establishing the legal enabling environment for decentralization, setting national environmental priorities and standards, establishing...[strategies to address social exclusion], and assuring compliance with national laws. Central government also has roles in supporting a variety of local efforts with finance and technical services.

Regions should not be seen, however, as the only locale for NRM, replacing all others. The challenge for Australia is to integrate and articulate such management across the existing tiers of governance, including the emerging regional groups, recognising the concurrence of responsibilities (Lane et al., 2004). As such, the matters 
and degree of devolution and adoption of responsibilities by regional groups should be carefully considered within this context of concurrency.

The principle of subsidiarity provides some guidance as to where environmental actions should be located (Follesdal, 1998; Ribot, 2002). Following this principle, decisions should be made at the lowest possible political-administration level. For NRM this means decisions that can be made by Landcare groups should be made by them, decisions that can be made by representative local and regional bodies should be made at that level, while those requiring state-level deliberation and beyond should be effected at those levels.

\section{Conclusions}

This paper has reviewed the 'new' regional delivery of NRM in Australia against the ideal of democratic decentralisation and described the mismatch, specifically in terms of representation, accountability, fairness and the secure transfer of power to local people. The groups do not represent the demos (Dovers, 2003; Moore, forthcoming) and hence are not democratic. This lack of representation, especially where there is nomination rather than election of members, confounds accountability, especially downwards to local people, as they have no recourse to dismissal or other sanctions if they are dissatisfied with a member's performance. The transfer of power has been partially achieved for statutory groups by giving them legislative security, however, there is little evidence of a real transfer of power to them as part of these statutory arrangements.

Given this status check, what can be concluded about the opportunities for agency for local people in NRM and what might be some complimentary roles for governments? Possibilities for local people exist in at least three places. First, elected representation of local people can be pursued/maintained through adjustment of existing 
statutory arrangements and the careful drafting of new arrangements (e.g. in Western Australia). Statutory is not synonymous with members being appointed by the Minister. Second, community members on regional groups have an unprecedented opportunity, which is currently being realised, to work with State Governments as partners. Opportunities for the co-production of knowledge may become possible. Third, if subsidiarity is pursued there should be opportunities for local people to engage at a range of levels of governance around natural resources rather than seeing regional processes as the only point of entry. These preceding three points are based on the supposition that regional people want these responsibilities (Wallace, 2003).

Governments need to and must be involved for reasons of democracy, efficiency and effectiveness. Successful NRM, independent of the scale at which it is pursued, depends on substantial investments by governments (Curtis et al., 2002). The challenge with regional NRM in Australia is to begin affecting transfers in power to these regional groups while at the same time ensuring they develop accountable representation. Part of this transfer can be achieved by ensuring that reporting requirements relate to minimum standards rather than elaborate centralised planning processes (Ribot, 2002).

In terms of transformations that might be part of this new regional delivery landscape, the most exciting possibilities are those offered by local government. This sphere of government has existing environmental responsibilities, which are still being realised (Binning et al., 1999). Through their elected base, they provide an immediately available means for providing accountable representation. The challenge now is how to transform local government and the rapidly developing regional delivery approach to NRM in Australia to move closer to the ideal of democratic decentralisation. 


\section{Acknowledgments}

The insights provided by members of the Swan and Avon Catchment Councils and the Glenelg Hopkins and North East Catchment Management Authorities made this work possible. Viv Read's contributions to this research are also acknowledged. Funding was provided through the Murdoch University (Australia) Research Excellence Grant Scheme.

\section{References}

Agrawal, A. (2000) "Community" and natural resource conservation, in: F.P. Gale \& R.M. M'Gonigle (ed.s) Nature, Power, Production: Towards an Ecological Political Economy, pp. 35-55 (Cheltenham, Edward Elgar).

Bates, G. (2003) Legal perspectives, in: S. Dovers \& S. Wild River (ed.s) Managing Australia's Environment, pp. 253-301 (Leichhardt, The Federation Press).

Bellamy, J.A. \& Johnson, A.K.L. (2000) Integrated resource management: moving from rhetoric to practice in Australian agriculture, Environmental Management, 25, pp. 265-80.

Binning, C., Young, M. \& Cripps, E. (1999) Beyond roads, rates and rubbish: opportunities for local government to conserve native vegetation, Research Report No. 1/99 (Canberra, National Research and Development Program on Rehabilitation, Management and Conservation of Remnant Vegetation, Environment Australia Biodiversity Group).

Byron, I. (2004) Assessing and managing burnout in Landcare members, leaders and coordinators, PhD thesis (Wagga Wagga, Charles Sturt University).

CIE \& CSIRO (Centre for International Economics \& Commonwealth Scientific and Industrial Research Organisation) (1999) Midterm review of the Natural Heritage 
Trust, [Online] URL: http://www.nht.gov.au/review/mtrfinrpt/index.html (Accessed 23 May 2005).

Commonwealth of Australia (2005) Overview of the Australian Government's natural resource management initiatives: protecting, conserving, repairing, Department of Agriculture, Fisheries and Forestry and the Department of Environment and Heritage, Canberra, [Online] URL: http://www.nrm.gov.au/publications/nrmoverview/index.html\#download (Accessed 23 May 2005).

Curtis, A. (2003) The Landcare experience, in: S. Dovers \& S. Wild River (ed.s) Managing Australia's Environment, pp. 442-60 (Leichhardt, The Federation Press).

Curtis, A. \& Lockwood, M. (2000) Landcare and catchment management in Australia: lessons for state-sponsored community participation, Society and Natural Resources, 13, pp. 61-73.

Curtis, A., Shindler, B. \& Wright, A. (2002) Sustaining local watershed initiatives: lessons from Landcare and Watershed Councils, Journal of the American Water Resources Association, 38, pp. 1207-16.

Dahl, R.A. (1989) Democracy and its critics (New Haven and London, Yale University Press).

Dale, A. \& Bellamy, J. (1998) Regional resource use planning in rangelands: an Australian review, Occasional Paper 06/98 (Land and Water Resources Research and Development Corporation, St Lucia).

Dobson, A. (1996) Representative democracy and the environment, in: W.M. Lafferty \& J. Meadowcroft (ed.s) Democracy and the Environment: Problems and Prospects, pp. 124-39 (Cheltenham, Edward Elgar). 
Dore, J., Woodhill, J., Andrews, K. \& Keating, C. (2003) Sustainable regional development: lessons from Australian efforts, in: S. Dovers \& S. Wild River (ed.s) Managing Australia's Environment, pp. 154-80 (Leichhardt, The Federation Press).

Douglas, M. \& Wildavsky, A. (1982) Risk and culture: an Essay on the selection of technical and environmental dangers (Berkeley, University of California Press).

Dovers, S. (2003) Reflecting on three decades: a synthesis, in: S. Dovers \& S. Wild River (ed.s) Managing Australia's Environment, pp. 515-35 (Leichhardt, The Federation Press).

Ewing, S. (2003) Catchment management arrangements, in: S. Dovers \& S. Wild River (ed.s) Managing Australia's Environment, pp. 393-412 (Leichhardt, The Federation Press).

Follesdal, A. (1998) Survey article: subsidiarity, The Journal of Political Philosophy, 6, pp. 190-218.

Jennings, S. J. \& Moore, S.A. (2000) The rhetoric behind regionalisation in Australian natural resource management: myth, reality and moving forward, Journal of Environmental Policy and Planning, 2, pp. 177-91.

Kellert, S. R., Mehta, J.N., Ebbin, S.A. \& Lichtenfeld, L.L. (2000) Community natural resource management: promise, rhetoric, and reality, Society and Natural Resources, 13, pp. 705-15.

Lane, M.B. (2003a) Decentralization or privatization of environmental governance? Forest conflict and bioregional assessment in Australia, Journal of Rural Studies, 19, pp. 283-94. 
Lane, M.B. (2003b) Participation, decentralization, and civil society: indigenous rights and democracy in environmental planning, Journal of Planning Education and Research, 22, pp. 360-73.

Lane, M.B., McDonald, G.T. \& Morrison, T.H. (2004) Decentralisation and environmental management in Australia: a comment on the prescriptions of the Wentworth Group, Australian Geographical Studies, 42, pp. 103-15.

McGinnis, M.V., Woolley, J. \& Gamman, J. (1999) Bioregional conflict resolution: rebuilding community in watershed planning and organizing, Environmental Management, 24, pp. 1-12.

Moore, S.A. (forthcoming) Regional delivery of natural resource management in Australia: is it democratic and does it matter?, in: J. Martin and R. Eversole (ed.s) Participation and Governance in Regional Development (Aldershot, Ashgate).

O'Neill, J. (2001) Representing people, representing nature, representing the world, Environment and Planning C: Government and Policy, 19, pp. 483-500.

Ribot, J.C. (2002) Democratic decentralization of natural resources: institutionalizing popular participation (Washington D.C., World Resources Institute).

Smith, P.D. \& McDonough, M.H. (2001) Beyond public participation: fairness in natural resource decision making, Society and Natural Resources, 14, pp. 239-49.

Virtanen, P. (2003) Local management of global values: community-based wildlife management in Zimbabwe and Zambia, Society and Natural Resources, 16, pp. 17990.

Wallace, K.J. (2003) Confusing means with ends: a manager's reflections on experience in agricultural landscapes of Western Australia, Ecological Management and Restoration, 4, pp. 23-8. 
Webler, T., Tuler, S. \& Krueger, R. (2001) What is a good public participation process? Five perspectives from the public, Environmental Management, 27, pp. 435-50. Wentworth Group (2002) Blueprint for a living continent. A way forward from the Wentworth Group of concerned scientists (Sydney, WWF Australia).

Working with People (with Alexander Holm \& Associates) (2004) Case studies on community group and volunteer engagement in natural resource management (Fremantle, Working with People). 
Table 1. Changes in activities, roles and expectations between Landcare and regional NRM groups

\begin{tabular}{|c|c|c|}
\hline Activity & $\begin{array}{l}\text { Landcare (dominant } \\
\text { paradigm 1986-2000) }\end{array}$ & $\begin{array}{l}\text { Regional NRM group (emerging paradigm } \\
2000 \text { onwards) }\end{array}$ \\
\hline $\begin{array}{l}\text { On-ground } \\
\text { work }\end{array}$ & $\begin{array}{l}\text { Undertake works on individual } \\
\text { farms/reserves or small groups } \\
\text { of farms. }\end{array}$ & $\begin{array}{l}\text { Allocate resources to others to complete on- } \\
\text { ground work. }\end{array}$ \\
\hline Planning & $\begin{array}{l}\text { Planning for implementation of } \\
\text { grant projects on individual } \\
\text { farms/reserves or small groups } \\
\text { of farms. }\end{array}$ & $\begin{array}{l}\text { Aggregate \& express regional needs. } \\
\text { Prepare \& implement regional plans. } \\
\text { Broker \& coordinate new projects. }\end{array}$ \\
\hline Resources & $\begin{array}{l}\text { Access resources from } \\
\text { governments, via project grants, } \\
\text { to support local efforts. }\end{array}$ & $\begin{array}{l}\text { Establish priorities in investment strategy to } \\
\text { attract funding from governments \& other } \\
\text { partners. } \\
\text { Build and maintain partnerships to access } \\
\text { resources. }\end{array}$ \\
\hline Participation & $\begin{array}{l}\text { Mobilise participation in local } \\
\text { groups \& projects. }\end{array}$ & $\begin{array}{l}\text { Foster cooperation among all interests. } \\
\text { Link \& support local groups. }\end{array}$ \\
\hline Learning & Initiate and support. & Develop learning, as part of capacity building. \\
\hline Monitoring & $\begin{array}{l}\text { Report on expenditure \& outputs } \\
\text { from projects to government } \\
\text { fundors. }\end{array}$ & $\begin{array}{l}\text { Monitor \& report to partners on regional plan } \\
\text { implementation against agreed resource } \\
\text { condition targets. }\end{array}$ \\
\hline $\begin{array}{l}\text { Corporate } \\
\text { governance }\end{array}$ & $\begin{array}{l}\text { Groups of 20-30 landholders. } \\
\text { Investment decisions made by } \\
\text { governments. }\end{array}$ & $\begin{array}{l}\text { Professional board, business plan, auditing. } \\
\text { Investment decisions made by group in } \\
\text { partnership with governments. }\end{array}$ \\
\hline Accountability & $\begin{array}{l}\text { Accountable for expenditure of } \\
\text { small grants \& project } \\
\text { outcomes. }\end{array}$ & $\begin{array}{l}\text { Accountable for expenditure of government } \\
\text { funds \& regional outcomes. }\end{array}$ \\
\hline $\begin{array}{l}\text { Expected } \\
\text { outcomes }\end{array}$ & 'Fair' allocation of funds. & $\begin{array}{l}\text { Improvement in resource condition towards } \\
\text { specified targets. }\end{array}$ \\
\hline
\end{tabular}

Sources: Bellamy and Johnson (2000); Curtis and Lockwood (2000); Curtis et al. (2002); Working with People (2004). 
Table 2. Administrative characteristics of regional groups reviewed

\begin{tabular}{|c|c|c|c|c|c|}
\hline $\begin{array}{l}\text { Regional group \& } \\
\text { year formed }^{\mathrm{a}}\end{array}$ & Role of group & $\begin{array}{l}\text { No. } \\
\text { members }\end{array}$ & $\begin{array}{l}\text { Appointment } \\
\text { method }\end{array}$ & $\begin{array}{l}\text { Selection } \\
\text { criteria }\end{array}$ & $\begin{array}{l}\text { No. } \\
\text { staff }^{\mathrm{c}}\end{array}$ \\
\hline $\begin{array}{l}\text { Glenelg Hopkins } \\
\text { Catchment } \\
\text { Management } \\
\text { Authority, VIC } \\
\text { (1997) [GHCMA] }\end{array}$ & $\begin{array}{l}\text { Regional } \\
\text { strategy } \\
\text { development, } \\
\text { performance as } \\
\text { a Board }\end{array}$ & $\begin{array}{l}13 \text { (at least } \\
1 \mathrm{SG})\end{array}$ & $\begin{array}{l}\text { Expressions of } \\
\text { interest from } \\
\text { community, then } \\
\text { Ministerial } \\
\text { appointment }\end{array}$ & Skills & 45 \\
\hline $\begin{array}{l}\text { North East } \\
\text { Catchment } \\
\text { Management } \\
\text { Authority, VIC } \\
\text { (1997) [NECMA] }\end{array}$ & $\begin{array}{l}\text { Strategic } \\
\text { direction \& } \\
\text { policy, } \\
\text { corporate } \\
\text { planning, } \\
\text { regional strategy }\end{array}$ & 13 (2SG) & $\begin{array}{l}\text { Expressions of } \\
\text { interest from } \\
\text { community, then } \\
\text { Ministerial } \\
\text { appointment }\end{array}$ & $\begin{array}{l}\text { Skills in } \\
\text { NRM, } \\
\text { business, } \\
\text { government } \\
\text { relations }\end{array}$ & 36 \\
\hline $\begin{array}{l}\text { Avon Catchment } \\
\text { Council, } \\
\text { WA (1994) [ACC] }\end{array}$ & $\begin{array}{l}\text { Oversee } \\
\text { regional NRM } \\
\text { delivery }\end{array}$ & $\begin{array}{l}15(9 \mathrm{C}, \\
6 \mathrm{SG})\end{array}$ & $\begin{array}{l}\text { Nomination \& } \\
\text { then election } \\
\text { within sub- } \\
\text { regions }\end{array}$ & Skills & 6.5 \\
\hline $\begin{array}{l}\text { Swan Catchment } \\
\text { Council, WA } \\
\text { (1994) }[\mathrm{SCC}]\end{array}$ & $\begin{array}{l}\text { Regional } \\
\text { strategy } \\
\text { preparation }\end{array}$ & $\begin{array}{l}13(6 \mathrm{C} \\
\text { from sub- } \\
\text { regions, } \\
3 \mathrm{SG}, 4 \\
\text { others })\end{array}$ & $\begin{array}{l}\text { Nomination by } \\
\text { sub-regions then } \\
\text { selection by } \\
\text { Council }\end{array}$ & $\begin{array}{l}\text { Skills, } \\
\text { knowledge } \\
\text { of sub-region }\end{array}$ & 7 \\
\hline
\end{tabular}

${ }^{\mathrm{a}}$ Victorian groups were preceded by non-statutory organisations. ${ }^{\mathbf{b}} \mathrm{C}-\mathrm{Community}$; SG - State Government. 'Victorian groups have statutory responsibilities for water management, contributing to higher staff numbers, e.g., Glenelg Hopkins has 20-25 staff dedicated to waterways management. 
Table 3. Features of accountability raised by regional groups

\begin{tabular}{|l|l|l|}
\hline $\begin{array}{l}\text { Regional } \\
\text { group }\end{array}$ & Important features & Suggested improvements \\
\hline $\begin{array}{l}\text { Glenelg } \\
\text { VIC }\end{array}$ & $\begin{array}{l}\text { Accountable to State \& } \\
\text { Commonwealth Governments, not } \\
\text { local communities, annual report, } \\
\text { communications plan. }\end{array}$ & $\begin{array}{l}\text { Removal of waterways } \\
\text { management tariff }{ }^{\text {a }} \text { has resulted in } \\
\text { lower local ownership of regional } \\
\text { group processes. }\end{array}$ \\
\hline $\begin{array}{l}\text { North East } \\
\text { CMA, VIC }\end{array}$ & $\begin{array}{l}\text { Accountable to State \& } \\
\text { Commonwealth Governments, not } \\
\text { local communities, annual report, } \\
\text { communications plan, monthly } \\
\text { newspaper articles, community } \\
\text { forums. }\end{array}$ & $\begin{array}{l}\text { Accountability not an issue within } \\
\text { the broader community, better } \\
\text { community engagement if } \\
\text { waterways management tariff } \\
\text { reinstated. }\end{array}$ \\
\hline Avon CC, & $\begin{array}{l}\text { Accountable to partners (i.e. State } \\
\text { Wovernment), project management \& } \\
\text { reporting, financial reporting \& audit, } \\
\text { providing information to regional } \\
\text { community members, open meetings. }\end{array}$ & $\begin{array}{l}\text { Business plan \& annual report, } \\
\text { revised partnership arrangements } \\
\text { with State Government to improve } \\
\text { accountability, improved corporate } \\
\text { governance. }\end{array}$ \\
\hline Swan CC, WA & $\begin{array}{l}\text { Project management \& reporting, } \\
\text { financial reporting \& audit, meeting } \\
\text { minutes publicly available. }\end{array}$ & $\begin{array}{l}\text { Improved project reporting, } \\
\text { improved reporting by State } \\
\text { Government partners, improved } \\
\text { corporate governance. }\end{array}$ \\
\hline
\end{tabular}

${ }^{a}$ A waterways management tariff was formerly applied to all rural landholders and collected by the CMAs for water management works. It was abolished in 1999 ( Ewing 2003). 
Table 4. Perceptions of fairness

\begin{tabular}{|l|l|l|}
\hline $\begin{array}{l}\text { Regional } \\
\text { group }\end{array}$ & Perceptions from within & Perceptions from 'outside' \\
\hline $\begin{array}{l}\text { Henelg } \\
\text { CMA, VIC }\end{array}$ & $\begin{array}{l}\text { Processes are considered fair, } \\
\text { generally Board represent all } \\
\text { interests. }\end{array}$ & $\begin{array}{l}\text { Local groups who have made submissions } \\
\text { expect to see outcomes in their local area, } \\
\text { community is more interested in outcomes } \\
\text { than whether processes have been fair. }\end{array}$ \\
\hline $\begin{array}{l}\text { North East } \\
\text { CMA, VIC }\end{array}$ & $\begin{array}{l}\text { Processes are fair, some } \\
\text { anxiety within the Board about } \\
\text { community acceptance of } \\
\text { decisions. }\end{array}$ & $\begin{array}{l}\text { Those not involved with Board are probably } \\
\text { concerned about fairness, enthusiastic } \\
\text { community groups unable to access funds } \\
\text { will question process fairness. }\end{array}$ \\
\hline $\begin{array}{l}\text { Avon CC, } \\
\text { WA }\end{array}$ & $\begin{array}{l}\text { Processes considered fair, } \\
\text { recognising that some } \\
\text { investment guidelines are } \\
\text { beyond group's control. }\end{array}$ & $\begin{array}{l}\text { Strategy likely to be regarded as unfair } \\
\text { because it is not intended to be equitable \& } \\
\text { there is poor understanding of ACC's } \\
\text { decisions \& processes, some special interest } \\
\text { groups may not see decisions as fair. }\end{array}$ \\
\hline $\begin{array}{l}\text { Swan CC, } \\
\text { WA }\end{array}$ & $\begin{array}{l}\text { Processes considered fair as } \\
\text { they are based on technical } \\
\text { merit \& priority targets. }\end{array}$ & $\begin{array}{l}\text { Will be social inequity in future funding. } \\
\end{array}$ \\
\hline
\end{tabular}

